\title{
Labour Force and Its Realization in Labour Relationships
}

\author{
Martina Kovalčíkováa
}

\begin{abstract}
The personal rights are the institute of civil law. They are the subject of legal regulation in Provisions $\S 11$ and follows of Slovak Civil Code. Current legal regulation does not offer their definition, only enumeration. Therefore, this situation makes good area for discovering if there are the next personal rights which have characteristic nature of this institute. It is important to analyze in which private relationships the personal right has the conditions for its full realization. It is important to discover in which kind of private relationships exist the personal rights which is typical for these relationships. This paper deals with the value of human personality-labour force. In the first part, the paper analyzes the nature of labour force and tries to show that labour force is the next personal right, using the method of analysis, induction, deduction, and synthesis. In the second part of the paper, it is labour force analyzed through its realization in labour relationships. This part of the paper tries to show that labour force is personal right typical for labour relationships, using the methods of analysis, synthesis, and generalization. The third part of the paper tries to evoke the discussion if the labour force is right or value.
\end{abstract}

\section{Keywords}

Personal rights, labour force, labour relationships

The area of personal rights has evolved some questions. Firstly, there is a question if it is used by the monisms or pluralisms in its characteristics. Monisms, it is a trend by which there is one general personal right which consists of several personal rights. Pluralisms, it is a trend by which there is not only one general personal right, but there are several personal rights. Secondly, there is a question how many personal rights are known and what is deemed for personal right and what is not. This situation is depending on this that current Slovak legislation has not the legal definition of personal right. For these reasons, Slovak Theory of Civil Law tries to define them through characteristic marks which they have in legal relationships. On this base, there is the typical enumeration of personal rights (Cirák 2008). This enumeration is the same with the enumeration of personal rights in Provision $\S 11$ of Slovak Civil Code. The theorists of Slovak Civil Law analyze these rights, but they do not take steps to discover if there are possibilities for existing to another personal right. For this reason, the value of human personality - labour force is analyzed and in the same way, the area of private relationships in which this value has the important position is analyzed, too.

aIT.UP Limited Company, Brezno, Slovak Republic

Correspondent Author:

Martina Kovalčíková, 33 ČSA Street, 97701 Brezno, Slovak Republic

E-mail: martina.kovalcikova@azet.sk 


\section{LABOUR FORCE LIKE PERSONAL RIGHT}

Some scientists and theorists deem the labour force as one of the personal rights (Telec 2007). Their framework consists of physical, psychical, qualification abilities, and working skills. For analyzing the character of labour force like a personal right, it must be discovered if this value has the all characteristic marks of personal right. These characteristic marks are made by the Theory of Slovak Civil Law.

(1) The first characteristic mark is an absolute character of personal right (Cirák 2008). This mark means that personal rights influence against everyone. This relationship is called like absolute relationship. The labour force influences against everyone. Everyone has the obligation to protect it or to respect it;

(2) The second characteristic mark is immaterial character (Lazar 2010). This means that this right consists of some parts of human personality which do not have material value. The labour force fulfils this condition, too. In labour relationship, person takes the wages for labour which was performed. Person is compensated for performance and labour force makes the possibilities for this performance;

(3) The third characteristic marks are generality and exclusivity (Lazar 2010). The generality means that personal right belongs to each physical person. Only condition which must be fulfilled is that the physical person must be born. Person does not fulfil another condition. Person must not achieve any age which is related to lawful age. It belongs to person which has not full legal ability or which legal ability is limited. The exclusivity means that only person decides how she/he uses her/his parties of personality. This using is determined by the sphere of realization of parties of personality by another person and it is limited by the borders of legal regulation. Each person has its own labour force which is dependent on its physical, psychical abilities, its qualifications and working skills. It follows that each person has its own level of labour force;
(4) How is mentioned personal right belong to person from her/his birth. Person does not lose its personal right when she/he is in legal relationship during her/his life. If yes, it will be the conflict with the nature of personal right which is connecting with person. It follows that personal right is ending by the death of person (Vojčík et al. 2009). This is another of characteristic mark of personal rights. Personal right exists during the whole life of person. Person is born with physical and psychical abilities which progress during her/his life and then approached to their qualification and working skills;

(5) From the above-mentioned characteristic mark, the scientists from civil law make another characteristic. This characteristic mark is that personal rights cannot be the subject of heredity (Vojčík et al. 2009). Labour force like value fulfils this mark too, because when the person died, the personal right disappears, too;

(6) It is mentioned that person has the option on disposition with its personal rights. This characteristic mark includes acts which may transfer the personal rights to another person. The parts of person's personality may not be separated. From this, the allegation results another characteristic that personal rights are not able to transfer (Cirák and Ficová 2008). The immaterial character means that labour force has not the value of property, so it can not be the subject of exchanging relationships;

(7) The last characteristic mark is that the personal rights are imprescriptible (Vojčík 2012). This means that labour force is different from right which has property value.

\section{REALIZATION OF LABOUR FORCE IN LABOUR RELATIONSHIPS}

It was mentioned that every person has her/his own labour force which is determined by the level of her/his mental and physical skills. It seems that labour force is a content of realization of right to life and 
right to protection of health. Physical skills are related to physical force with which employee may disposes. The intelligence and the special skills (verbal, psychomotor characteristics, memory, etc.) are related to mental skills. These skills are the subject of interest of legislator. They have an influence on quantity of performance of work and employee's labour tempo. In Provision $\S 133$ of Slovak Labour Code, it is regulated that the labour standards are determined by these employee's skills. These labour standards are made with the help by the social partners (regulation in collective agreement) or local authority which is created to protect the labour relationships. The employee has the right to respect her/his labour force (her/his physical and psychical skills) during the performance of dependent work. The labour force belongs to employee and employee does not lose it when she/he enters to the labour relationships.

The qualification is a content of labour force. The qualification consists of an education which employee received (Dolobáč 2012) and of education which he/she may receive during the labour relationships. The care about employee's education is a content of business social policy of employer. If an employer invests to the education of her/his employees, it is good idea for his/her business. This step is helpful if employer wants to innovating methods of labour production for the increment of labour productivity (Barinková 2014). The second benefit is that employer does not pay too much costs for education of new employees which may have these skills. Slovak Labour Code regulates the provisions with the duties which employer has against employees and their education and qualification. For example, the Provision $\S 153$ and the next of Slovak Labour Code which deals with deepening of qualification (Barinková 1996). In this way, it may be mentioned the Provision $\S 140$ of Slovak Labour Code which regulates the increment of qualification and the in-service courses (Barinková 1998).

The third content of labour force is the practical skills. Employee obtains the practical skills during the labour life/labour process. It seems like a type of know-how "employee's know-how" which employee uses when fulfil labour duties from labour contract. This is a significant mark when one employee differs from another. It follows from the fact that if two employees make the same labour activity, the procedure with which may fulfil this activity is different. It is a question if the employee's know-how may be submitted under the regulation of the right to intellectual property. Therefore, it is necessary to discover if there is fulfilled the condition of creativity. This area is out of regulation of Slovak Labour Code.

This analysis is not able to resolve which part of labour force has the main priority. It depends on each employee which part of labour force will be developed at higher level.

Labour force like value (right) may be considered as a priority for coming years. The development of science, technology, implementing the new innovative elements to the labour process may cause that value of labour force will increase. The employers will search the employees with necessary META quality ("META quality" means the ability to learn, the creativity, and the mental agility) more and more. For better competitiveness, the employers will be able to support the development of employee's labour force. These activities may bring the changes in the regulation, too.

The analyzation of the conditions of realization of labour force brings up that labour force is a value which character outlines that it relates with individual's personality and it has the assumptions to create like single personal right which is typical for labour relationships. Labour regulation (the area of qualification and standards of work) makes the area for realization of labour force with the system of duties which has the employer. These duties are directed to protect this part of individual's personality. The protection is the main principle of labour law. So it can be closed that labour force has the social character. 


\section{LABOUR FORCE-THE RIGHT OR THE VALUE}

Deliberately in this paper, the labour force is not connected with the right. The personal rights which are defined in the Provision $\S 11$ of Slovak Civil Code have their regulation in the Slovak Constitution. In Slovak Constitution, they are indicated like right. But neither article indicates the right to labour force. In the Article 35 Section 3 of Slovak Constitution, it is regulated the right to work. There is a question if this article is considered as the base for labour force and therefore, the labour force may be marked like right. In Slovak Constitutional Court's judgement No. II. ÚS $12 / 93$, it is stated "that the right to work we cannot sense like right to get the particular work for which the employee has the useful qualification". From this claim, it can be indicated that right to work is extensive and that it is a right to get just any work and it is not our important qualification. Therefore, it cannot be alleged that the right to work is based on labour force. The value of labour force has the characteristic marks of personal right. It can be reflected in intentions of that it is a right. Another development of this value and its legal regulation determine if the labour force become value or right.

\section{CONCLUSIONS}

Labour force like value of individual's personality is important especially for labour relationships. Its development contributes to development of employee's personality. Its development is a means for increasing the labour productivity and means of better competitiveness. Investing to employees which are able to develop their labour force must be the subject of interest of employer in the form of making the suitable working conditions and the subject of interest of legislators in the form of making suitable legal regulation which can be helpful to this development.

\section{References}

Barinková, M. 1996. "The Qualifying and Stabilizating Agreements in the Slovak Labour Code." Legal Horizon: Theoretical Journal for Law and State 79(5):415-420.

_. 1998. "The Legal Character of Obstacles to Work on the Part of Employee." Judicial Review: Journal for Legal Practice 50(12):8-15.

—. 2014. "The Knowledge Potential as a Regional Disparity." Pp. 36-68 in The Regionalism in Labour Law. Košice: University of Pavol Jozef Šafárik in Košice.

Cirák, J. 2008. "The Personal and Moral Rights at the Prepared Code.” Pp. 177-187 in The Draft of Legislative Intent of Codification of Private Law. Bratislava: Ministry of Justice of Slovak Republic.

Cirák, J. and S. Ficová. 2008. The Civil Law. General Part. Šamorín: Heuréka.

Dolobáč, M. 2012. "The Reciprocal Recongnition of Qualification in the European Union." Humanum: Miedzynarodowe Studia Spoleczno-Humanistyczne (Humanum: International Socio-Studies in the Humanities) 8(1):131-139.

Lazar, J. 2010. The Substantive Civil Law. I. part. Bratislava: Iura Edition.

Telec, I. 2007. “The Protected Rights of Personality.” Legal Reviews 15(8):271-281.

Vojčík, P. 2012. The Substantive Civil Law. I. part. Košice: University of P. J. Šafárik in Košice.

Vojčík, P., J. Krajčo, M. Lalík, J. Mazák, K. Plank, and J. Ťapák. 2009. The Civil Code With Commentary. 2nd ed. Bratislava: Iura Edition.

\section{Bio}

Martina Kovalčíková, Ph.D., Mgr., lawyer, IT.UP Limited Company, Brezno, Slovak Republic; research field: labour law. 